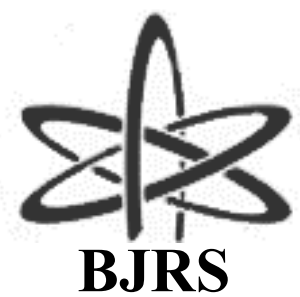

BRAZILIAN JOURNAL

$\mathrm{OF}$

RADIATION SCIENCES

08-01 (2020) 01-29

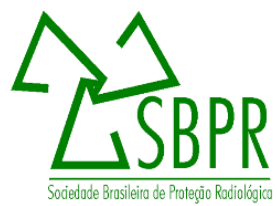

\title{
Radiological implications of using phosphogypsum as building material: a case study of Brazil
}

\author{
Mazzillia B. P., Campos $^{\text {a }}$ M. P., Nistia M. B., Saueia ${ }^{a}$ C.H.R., Máduar ${ }^{a}$ M. F. \\ ${ }^{a}$ Instituto de Pesquisas Energéticas e Nucleares (IPEN-CNEN/SP) \\ Postal code 05508-000, São Paulo, SP, Brazil \\ mazzilli@ipen.br
}

\begin{abstract}
Phosphogypsum, a waste byproduct derived from the production of phosphoric acid, is being worldwide stockpiled, posing concerns about the environmental problems originating from this practice. Considerations about the viability of the safe reuse of this material have been raised, among them its potential use as building material. However, as phosphogypsum can contain natural radionuclides in significant concentrations, using it as a building material has radiological implications, which presently prevent such application. In order to evaluate the feasibility of using phosphogypsum in the manufacturing of building elements such as bricks and plates, a comprehensive research was undertaken in Brazil, following a multiple approach. This research included studies related to: Brazilian phosphogypsum characterization; experimental determination of radon exhalation rate; and application of theoretical models to forecast both radon exhalation and external doses in dwellers. In this paper, a comprehensive review of the research carried out in Brazil is presented.
\end{abstract}

Keywords: Phosphogypsum; NORM, building materials; natural radionuclides.

ISSN: 2319-0612

Accepted: 2019-08-08 


\section{INTRODUCTION}

The mining and processing of phosphate rock, which is processed to phosphoric acid, generate NORM containing residues. This intermediate is then further processed into phosphate fertilizers and animal feeds. The main constituent of the Brazilian phosphate rock is the mineral apatite (carbonatite) of igneous origin, which presents in its composition traces of the $U$ and Th natural decay series.

According to the latest United States Geological Survey publication on phosphate rock production [1], twenty-one countries account for $99 \%$ of the global mine production, which was estimated in 261 million $t$ in 2016. Nearly $71 \%$ of all phosphate rock mined is reduced into phosphoric acid [2], which in turn results in large amounts of phosphogypsum (about 4-6 $\mathrm{t}$ of phosphogypsum for every tone of phosphoric acid). Globally, the phosphogypsum production reaches 160 million $\mathrm{t}$ [2], where the largest producers are located in the USA (as well as China, Africa and Middle East), especially in Florida, responding for $14-40 \%$ of the worldwide phosphogypsum production [3].

Brazil is the sixth largest phosphate rock producer, reaching 6.5 million $t$ in 2016 [1]. According to the National Department of Mineral Production (DNPM), there are 13 phosphate mines in operation in Brazil [4], whose locations and producers are depicted in Figure 1. Figure 2 presents the location of the 7 phosphate mine projects under development [5]. 
Figure 1: Phosphate mines and producers in operation in Brazil

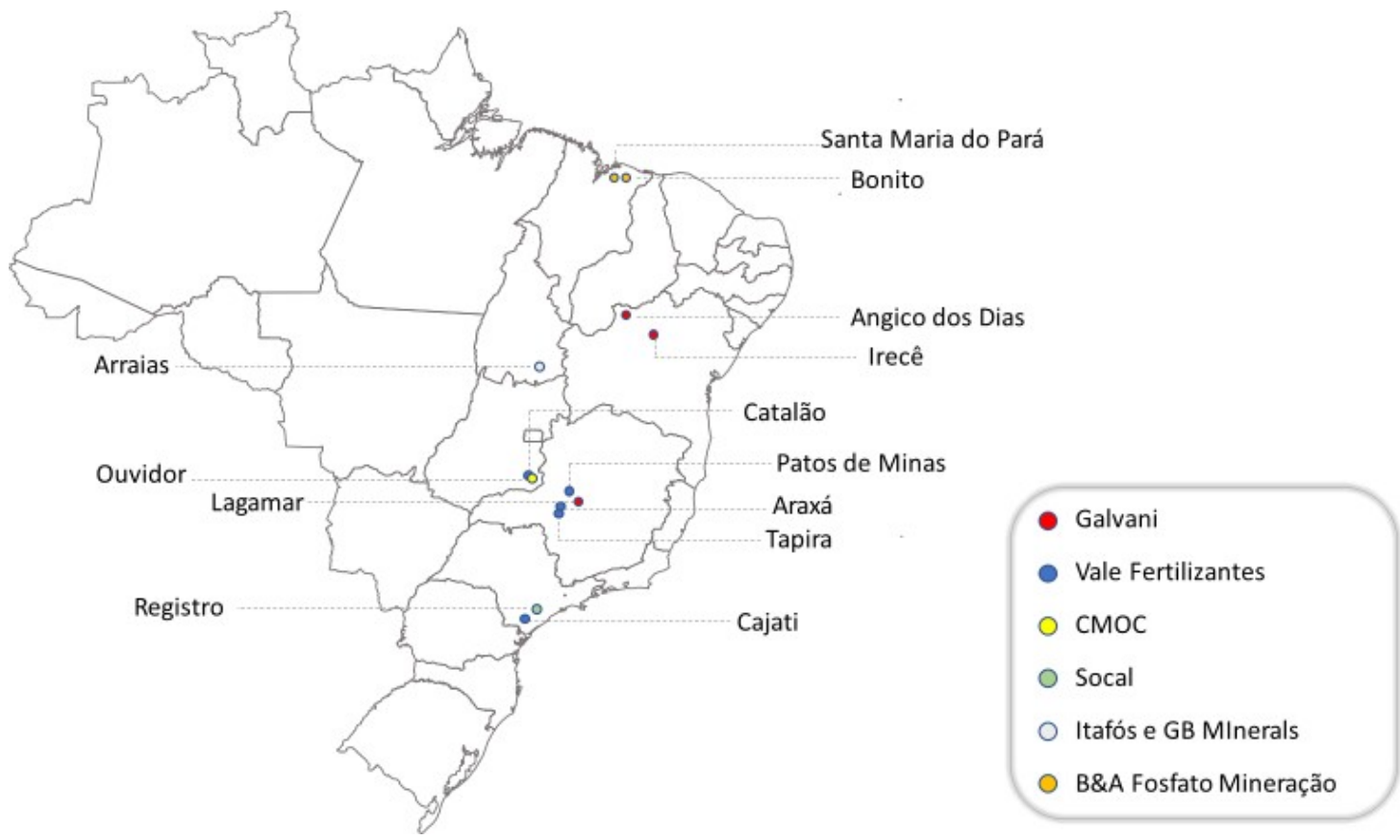

Source: adapted from [4]

Figure 2: Planned, prospecting phosphate mines in Brazil

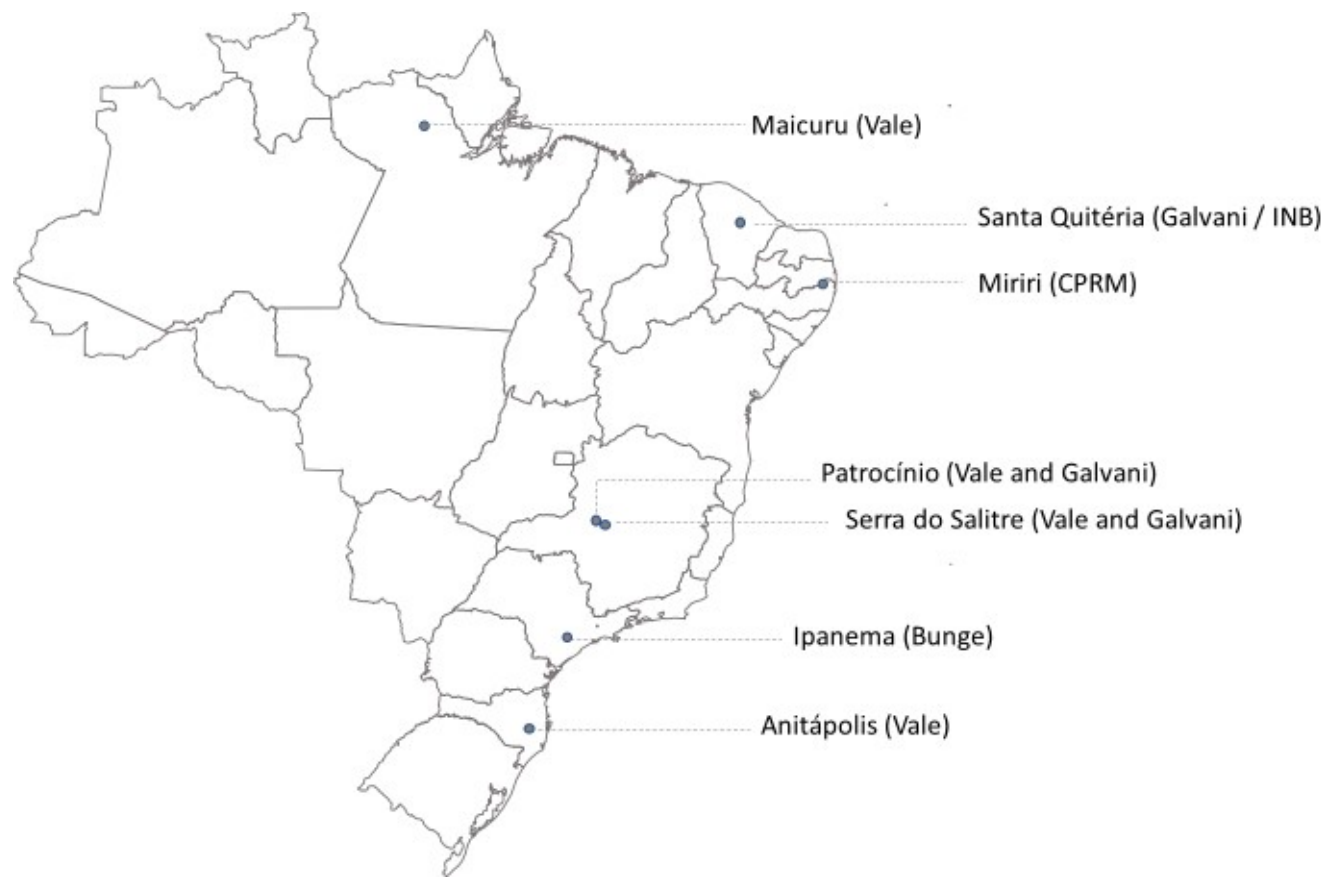

Source: adapted from [5]. 
Regarding to the planned and prospecting phosphate mines, two large projects are currently in process, both from Galvani/Yara industry: Serra do Salitre, expecting to produce 1.2 million $\mathrm{t}$ of phosphatic concentrate per year; and Santa Quitéria, whose phosphate deposits are associated with high concentrations of uranium and, therefore, its extraction is more complex and, by national legislation, demands a partnership with the Indústrias Nucleares do Brasil (INB).

\section{PHOSPHATE PRODUCTION IN BRAZIL}

Nearly $82 \%$ of all phosphate production is obtained in 5 mines, located in Tapira - currently the largest phosphate mine in the country; in Araxá - that incorporates 2 mines: Barreiro and F4; in Catalão and Ouvidor. These mines are operated by Mosaic and CMOC [4]. A major part of this production is processed in 4 main industrial sites, located in Sao Paulo (Cajati and Cubatão) and Minas Gerais (Uberaba) for phosphoric acid and phosphate fertilizer production, which in turn, generates phosphogypsum.

\subsection{Cajati - Mosaic Fertilizantes}

Located in Sao Paulo state (Figure 3), this site is owned by Mosaic Fertilizantes (former Vale Fertilizantes) and produces sulfuric acid (629 thousand t per year), phosphoric acid (222 thousand $\mathrm{t}$ per year) and dicalcium phosphate (635 thousand t per year), mainly for animal nutrition [6]. The phosphogypsum is stacked in the installation (shown in Figure 4) and, although it has been continuously growing, part of the phosphogypsum produced is locally distributed for agricultural purposes. 
Figure 3: Cajati and Cubatão locations within Sao Paulo state, Brazil

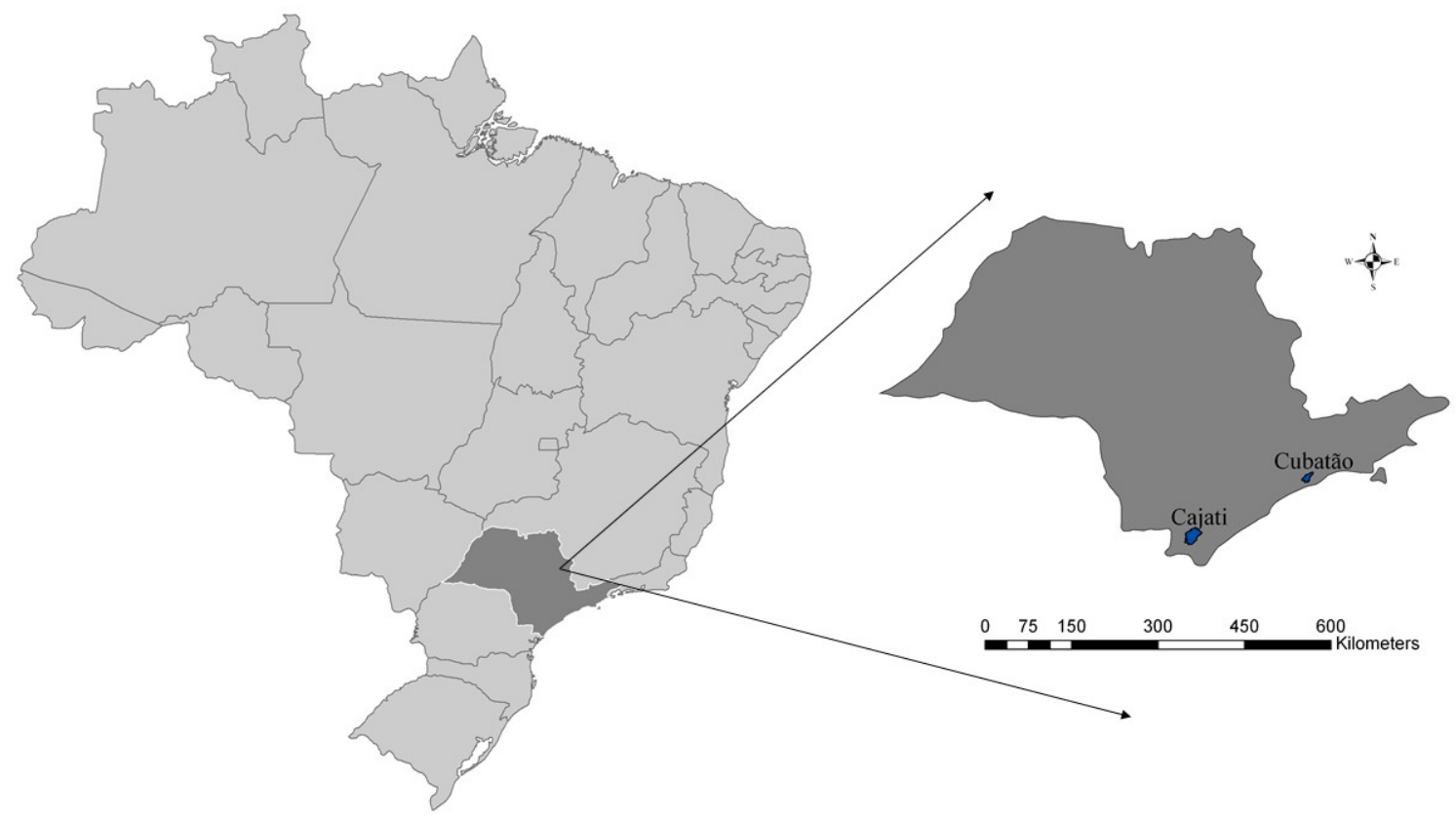

Figure 4: Phosphate mining and fertilizer complex in Cajati (owned by Mosaic Fertilizantes) and its phosphogypsum stack in 04/19/2016

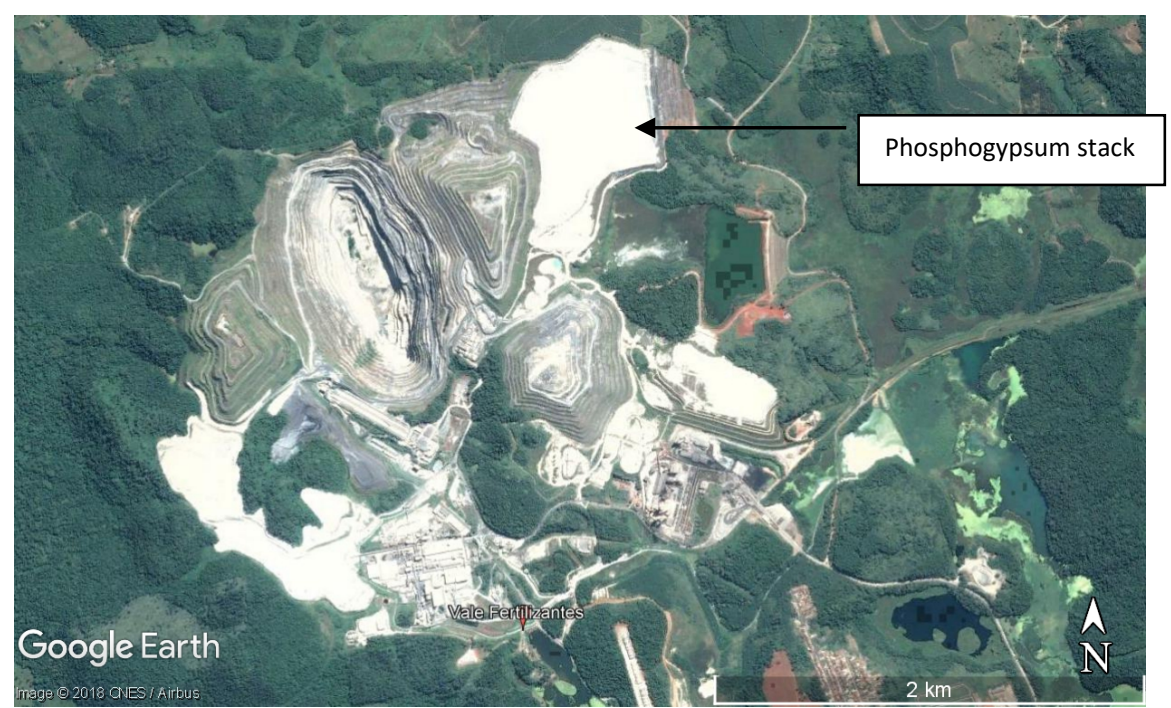

Source: Google Earth 


\subsection{Cubatão}

Located in Sao Paulo state (Figure 3), there are two distinct sites: one of them owned by Mosaic and the second one owned by CMOC.

Mosaic site operates for phosphate and nitrate fertilizers production. According to Vale [6], the installation produces ammonia (209 thousand t/year), nitric acid (299 thousand $t / y e a r)$, sulfuric acid (456 thousand t/year), phosphoric acid (146 thousand t/year), diammonium phosphate (DAP) and monoammonium phosphate (MAP) (337 thousand t/year), as well as ammonium nitrate. The phosphogypsum stack covers a significant area $\left(160,000 \mathrm{~m}^{2}\right)$ within the installation (shown in Figure 5) but it has been continuously diminished. This is owed by the fact that the phosphogypsum is being used for agricultural purposes and Cubatão has a privileged location, thirty kilometers away from Port of Santos. Unloaded trucks returning from this port are known to transport the phosphogypsum produced in Cubatão to several towns along their route [7].

Figure 5: Phosphogypsum stack at Cubatão phosphate fertilizer complex (owned by Mosaic Fertilizantes) in 06/16/2017

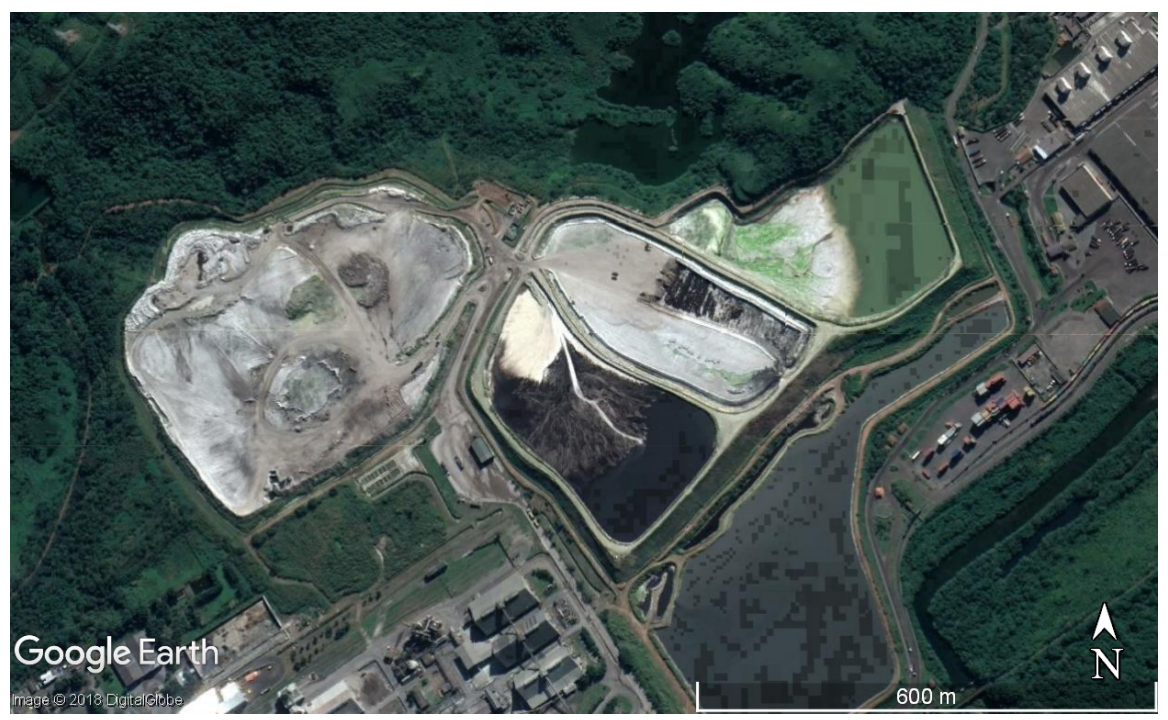

Source: Google Earth

The site owned by CMOC receives phosphate rock from the mine in Ouvidor (see Figure 1 for reference) mainly for fertilizer production. Along with another $\mathrm{CMOC}$ industrial plant in the city of Catalão - Goias state, the production in 2017 reached 1.15 million $t$ of fertilizer, 305 thou- 
sand $t$ of phosphoric acid and 179 thousand t of DCP. Alike the site owned by Mosaic in Cubatão, the phosphogypsum is stacked in the installation (Figure 6) but it has also been decreasing due to its transportation for agricultural purposes.

Figure 6: Phosphogypsum stack at Cubatão phosphate fertilizer complex (owed by CMOC) in 06/16/2017

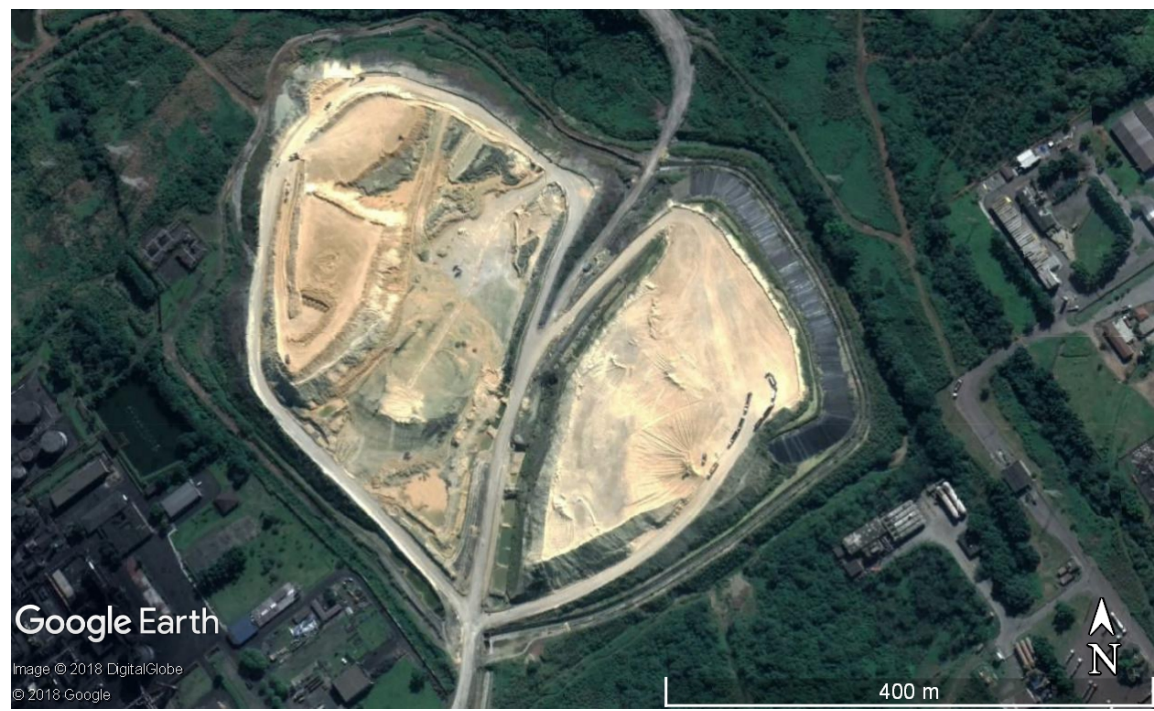

Source: Google Earth

\subsection{Uberaba}

Located in Minas Gerais state (Figure 7), this site is owned by Mosaic mostly producing sulfuric acid (2.6 million $\mathrm{t}$ per year) and phosphoric acid (907 thousand $\mathrm{t}$ per year) for phosphate fertilizers [6]. The phosphogypsum is stacked in the installation at a continuously growing rate of 4.4 million t/year, where 1.4 million $\mathrm{t}$ are commercialized for agricultural purposes [8], and covers a wide area of 1,625,000 $\mathrm{m}^{2}$ within the installation [7], as shown in Figure 8. 
Figure 7: Uberaba location within Minas Gerais state, Brazil

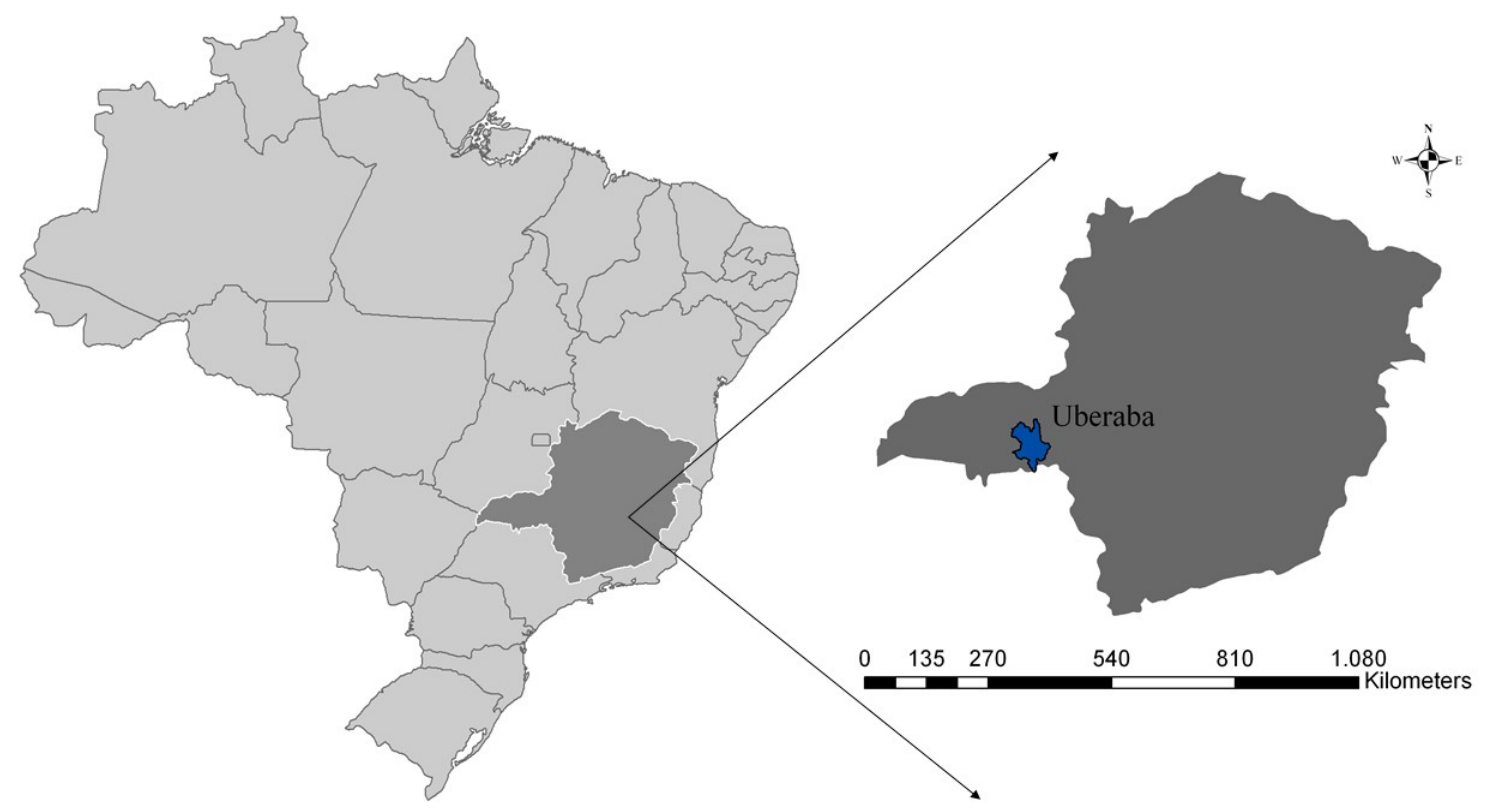

Figure 8: Phosphogypsum stack at Uberaba phosphate fertilizer complex (owned by Mosaic Fertilizantes) in 08/30/2017

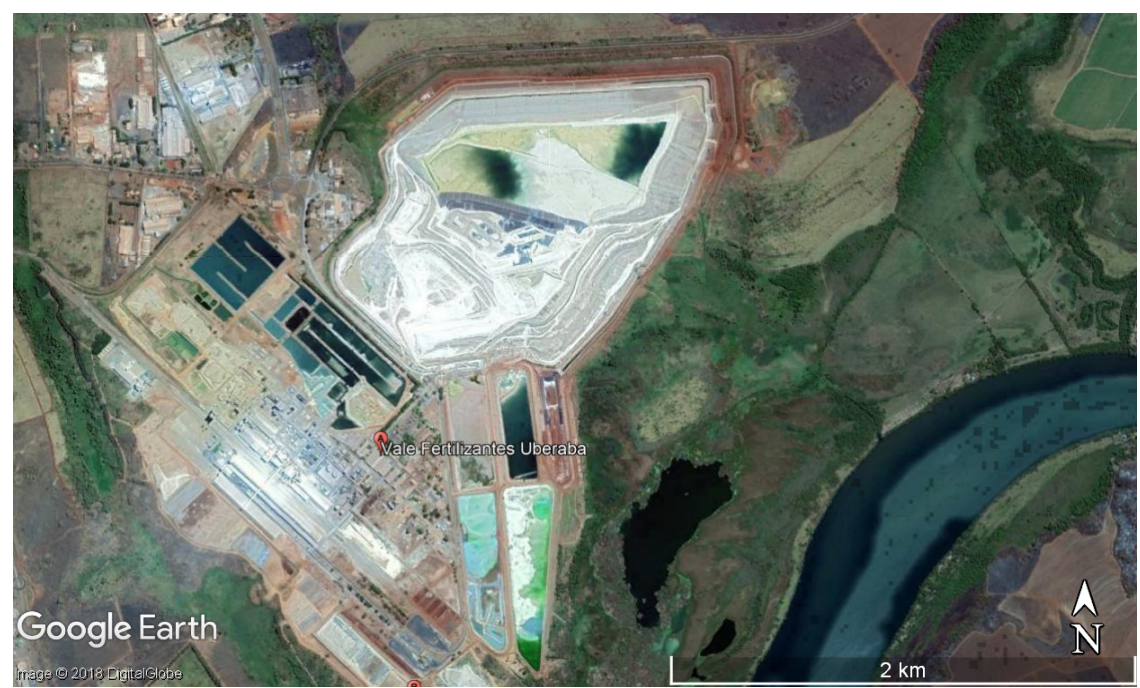

Source: Google Earth 


\subsection{Under development site - Santa Quitéria}

Santa Quitéria Project is a consortium of two companies, Galvani and INB, to explore and process collophanite - a phosphorusuraniferous ore located in Itataia, Santa Quitéria - Ceará state (Figure 9). According to its Report on Environmental Impact [9], the annual production is estimated in 1,050,000 $\mathrm{t}$ of phosphate derivatives, for animal nutrition and fertilizer production, as well as $1,600 \mathrm{t}$ of uranium. Generally, this project involves the construction and operation of an open mine pit, two mineral process units - phosphate and uranium concentrate, a phosphoric acid unit production and its consequential phosphogypsum production, which will be stacked within the installation.

Figure 9: Santa Quitéria location within Ceará state, Brazil

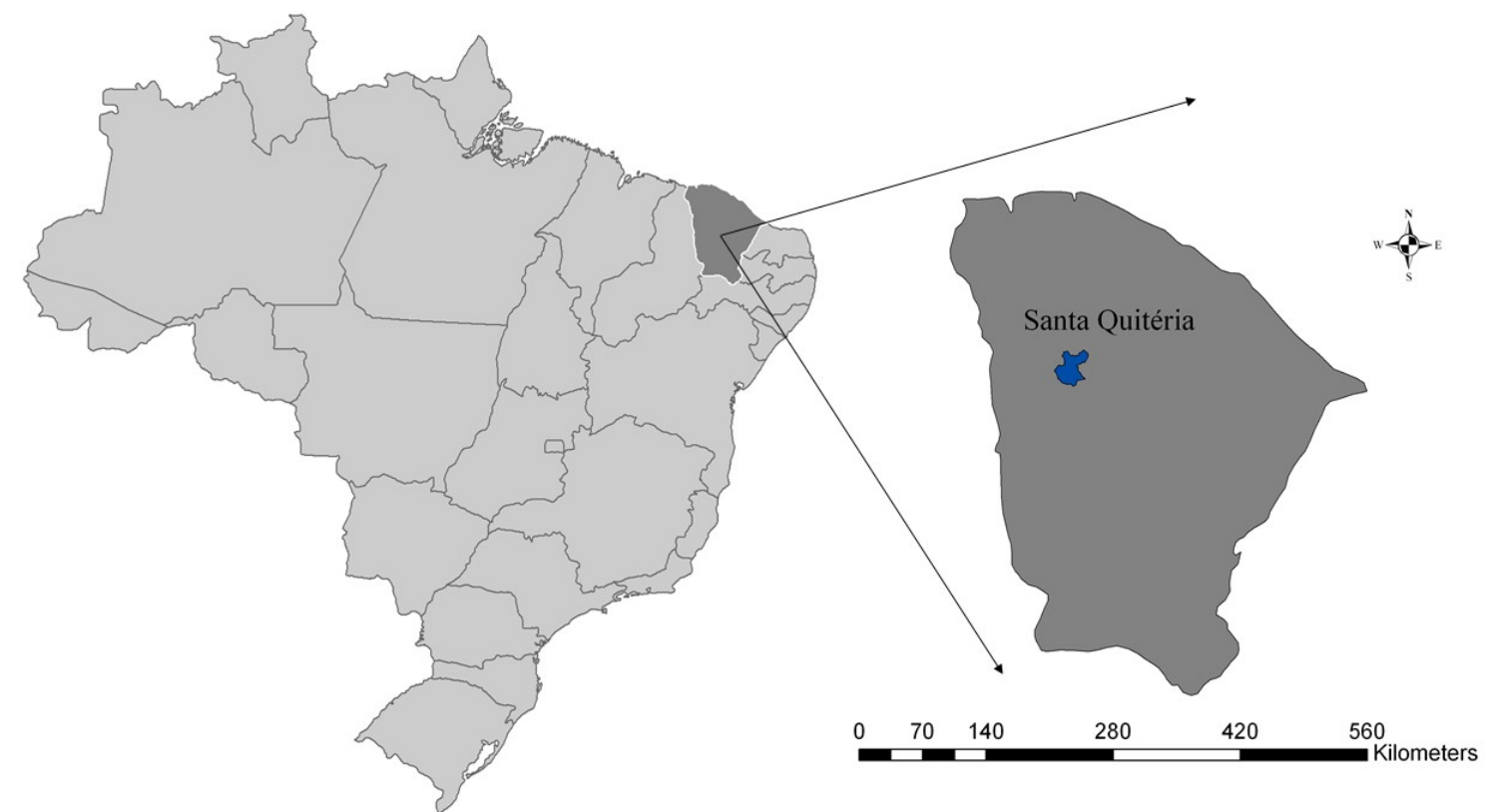




\subsection{Legacy site - Imbituba}

In the 1980s, a well stablished carbochemical industry, called Indústria Carboquímica Catarinense - ICC, produced phosphoric acid using wet acid methods in the city of Imbituba, Santa Catarina state (Figure 10). As a consequence, two large phosphogypsum stacks were formed: Stack 1 and Stack 2.

Figure 10: Imbituba location within Santa Catarina state, Brazil

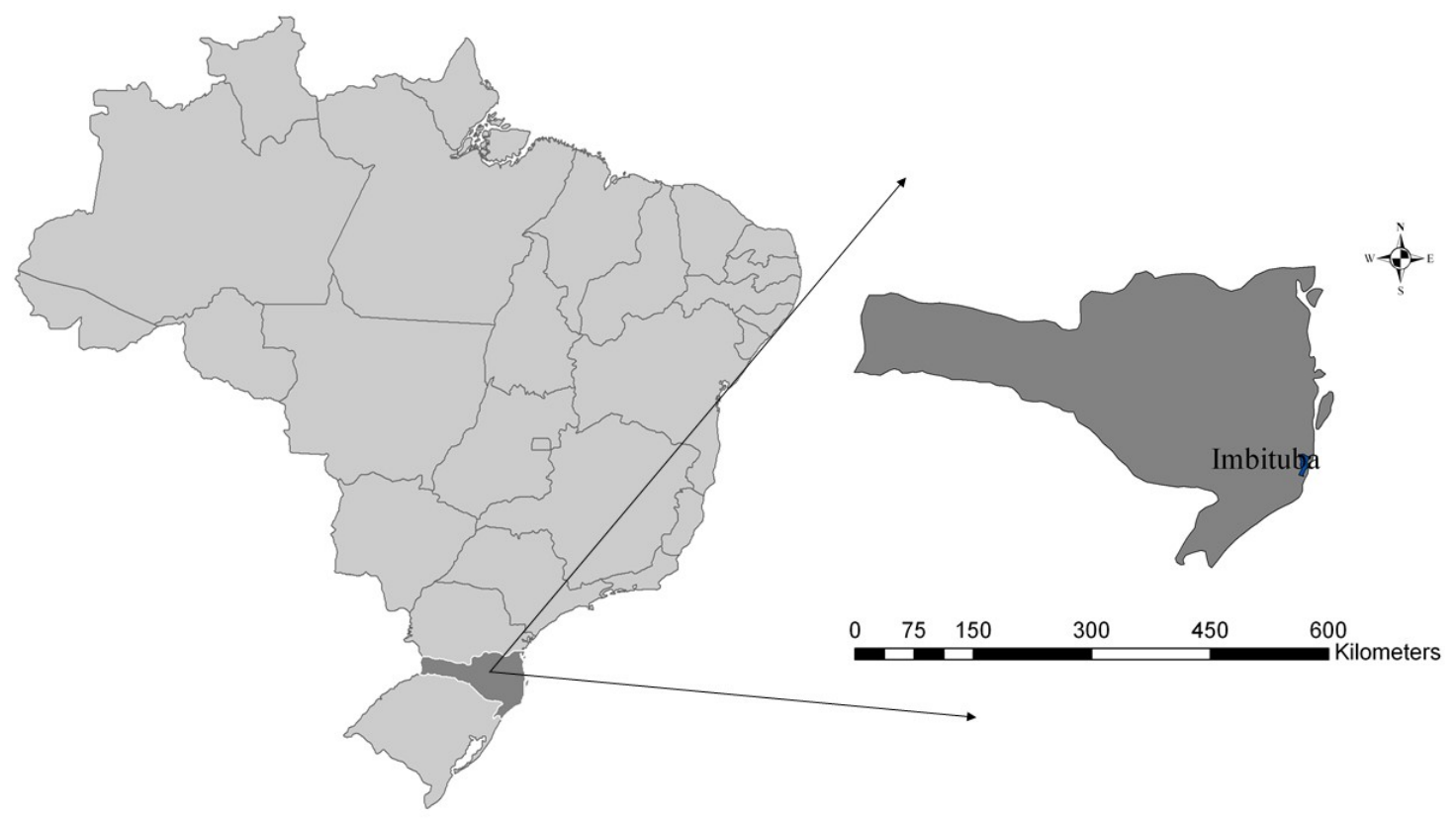

The company ceased its activities in 1997, and the PG disposal sites were not immediately remediated. According to [10], the newest PG pile, called Stack 1, embody $460,000 \mathrm{~m}^{2}$ and is $30 \mathrm{~m}$ high, formed by phosphate products originated from Araxá - MG (see Figure 1 for reference). Figure 11 presents the latest aerial photography from Stack 1.

The oldest pile, Stack 2, comprises 70,000 $\mathrm{m}^{2}$ and 500,000 $\mathrm{t}$ of $\mathrm{PG}$, mainly from phosphate products that came from Florida, USA and Morocco. Figure 12 is a chronological representation of this pile, with its latest photography depicted in Figure 13. 
Figure 11: Phosphogypsum stack 1 at Imbituba (formerly owned by Indústria Carboquímica Catarinense - ICC) in 06/13/2016

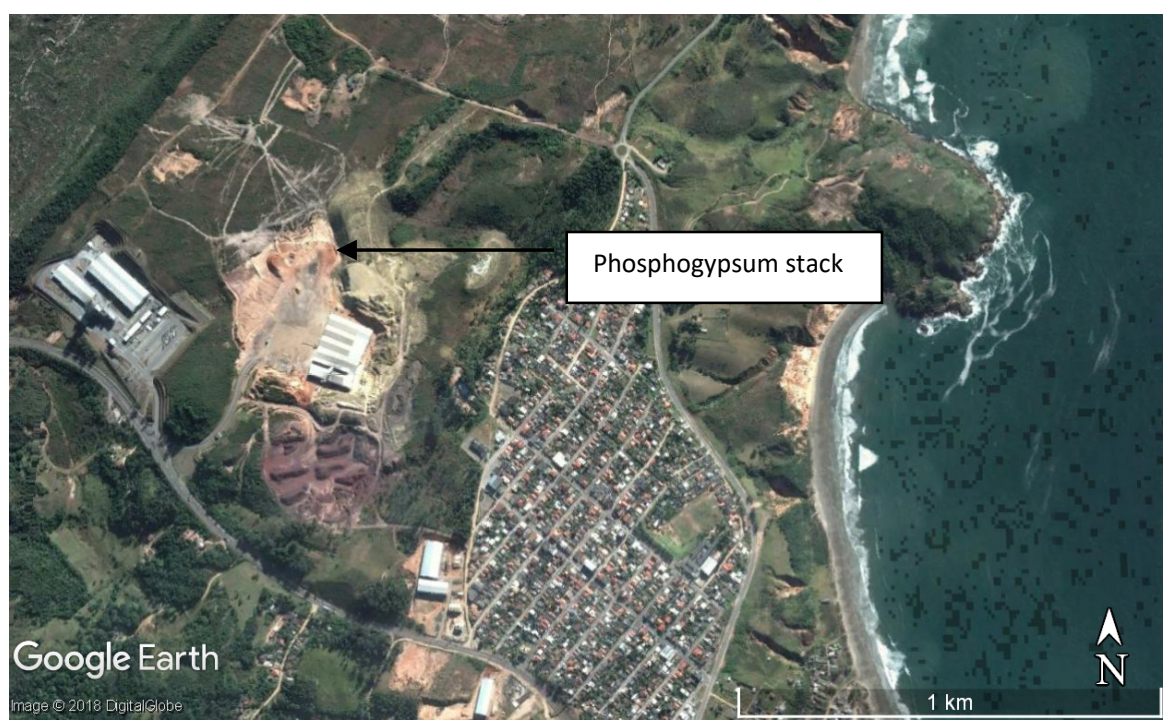

Source: Google Earth

Figure 12: Phosphogypsum stack 2 at Imbituba in (a) 09/16/2003 and (b) 08/13/2009

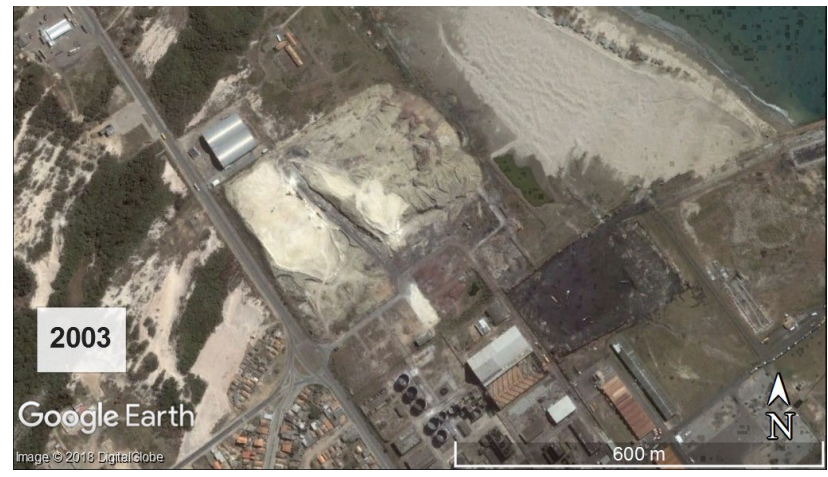

(a)

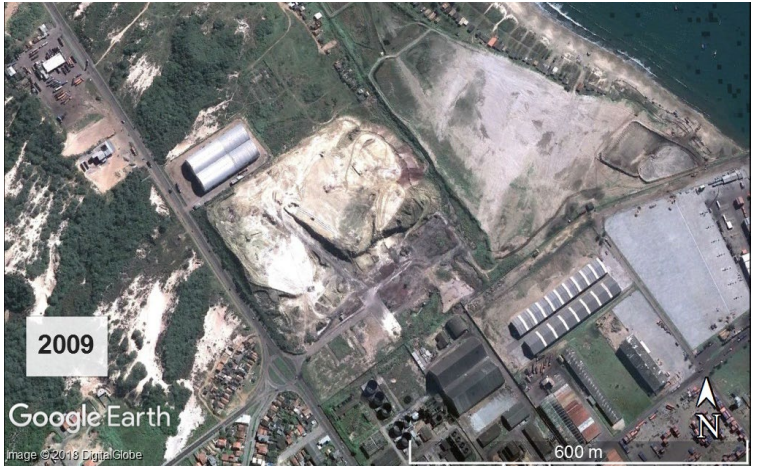

(b)

Source: Google Earth 
Figure 13: Phosphogypsum stack 2 at Imbituba in 10/23/2017

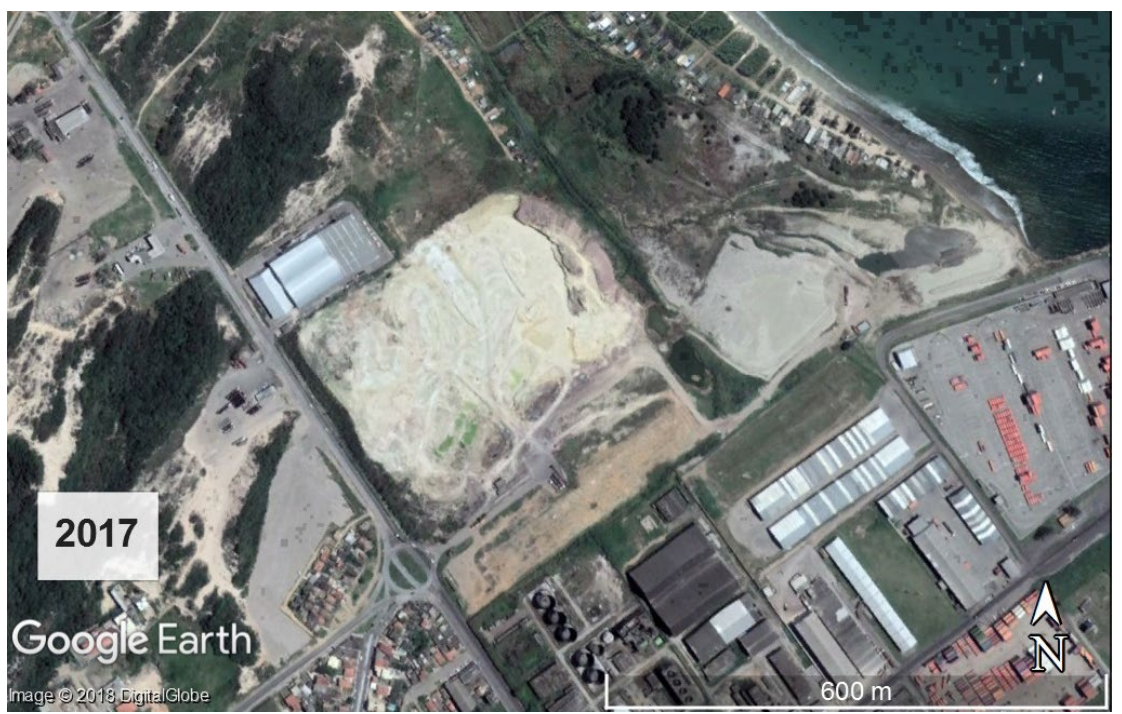

Source: Google Earth

Since the ICC closure, the stacks have been owned by the company Sulgesso (formerly Engessul) and the PG is commercialized for soil amendments, sold for neighbor states as well as Uruguay and Paraguay [11]. More recently, [12] has published an interesting study using the PG from Imbituba to treat saline soils. The authors have found that, not only this treatment did not increase the concentrations of ${ }^{226} \mathrm{Ra}$ in the soil, but also has promoted a satisfactory reduction on its electrical conductivity.

Phosphogypsum is being worldwide stockpiled, posing concerns about the environmental problems originating from this practice. Considerations about the viability of the safe reuse of this material have been raised, among them its potential use as building material. However, as phosphogypsum can contain natural radionuclides in significant concentrations, using it as a building material has radiological implications, which presently prevent such application. In order to evaluate the feasibility of using phosphogypsum in the manufacturing of building elements such as bricks and plates, a comprehensive research was undertaken at IPEN, Brazil, following a multiple approach. This research included the radiological characterization of bricks and plates made with Brazilian phosphogypsum; the evaluation of the radiological impact of its use in dwellers, which comprises the evaluation of internal exposure due to radon inhalation and external exposure due to gamma 
radiation. An experimental house was built with phosphogypsum plates of different origins. The house was entirely lined with phosphogypsum and designed to perform a comprehensive radiological evaluation, including the modelling of the external dose indoors, measurement of the external gamma exposure and of radon concentrations. In this paper, a comprehensive review of the research carried out at IPEN is presented.

\section{CHARACTERIZATION OF BRAZILIAN PHOSPHOGYPSUM}

\subsection{Radionuclides flows following sulphuric acid acidulation}

The production of phosphoric acid and phosphogypsum can be described by the following reaction:

$\mathrm{Ca}_{10} \mathrm{~F}_{2}\left(\mathrm{PO}_{4}\right)_{6}+10 \mathrm{H}_{2} \mathrm{SO}_{4}+10 \mathrm{nH}_{2} \mathrm{O} \rightarrow 10 \mathrm{CaSO}_{4} \mathrm{nH}_{2} \mathrm{O}+6 \mathrm{H}_{3} \mathrm{PO}_{4}+2 \mathrm{HF}$

In the phosphate rock, the natural $U$ and Th decay-series are in equilibrium. During the industrial process, this equilibrium is disrupted, and the radionuclides migrate to intermediate, final products and by-products according to the solubility and chemical properties of each element. In terms of rounded figures, the production of 1 ton of phosphate results in the generation of 4-5 ton of phosphogypsum. The characterization of radionuclides in the Brazilian industries showed that radium isotopes, $\mathrm{Pb}-210, \mathrm{Po}-210$ and thorium isotopes fractionate preferentially to the phosphogypsum, where percentages (to phosphate rock) of 90\% (radium isotopes), 100\% (Pb-210), 78\% (Po-210) and $80 \%$ (thorium isotopes) are found. The uranium isotopes are predominantly incorporated in phosphoric acid as uranyl phosphate, sulphate or fluoride complexes. The flow diagram shows the distribution of radionuclides in the sulphuric acid extraction process (Figure 14). 
Figure 14: Flow diagram of distribution of radionuclides in the sulphuric acid extraction process

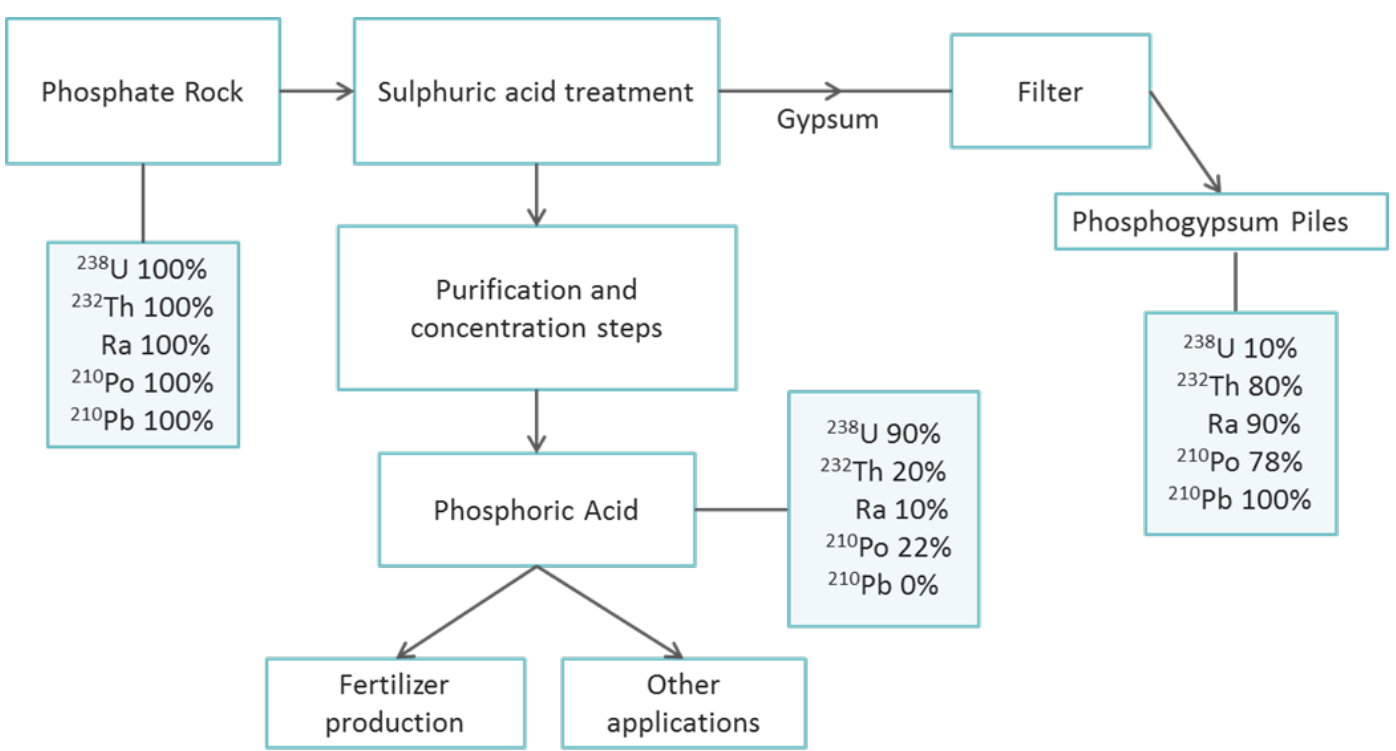

\subsection{Concentration of radionuclides in Brazilian phosphogypsum}

In the literature, several papers were published concerning the radiological characterization of the Brazilian phosphogypsum $[13,14,15,16,17]$. The range of activity concentration of radionuclides in the Brazilian phosphogypsum from the main producers are presented in Table 1. 
Table 1: Range of activity concentration in $\mathrm{Bq} \mathrm{kg}^{-1}$ for radionuclides in the Brazilian phosphogypsum.

\begin{tabular}{lccc}
\hline CMOC & $\begin{array}{c}\text { Mosaic Fertilizantes } \\
\text { (Anglo American) } \\
\text { (Vale Fertilizantes) } \\
\text { Cubatão }\end{array}$ & $\begin{array}{c}\text { Mosaic Fertilizantes } \\
\text { (Vale Fertilizantes) } \\
\text { Cubatão }\end{array}$ \\
\hline U-238 & $20-69$ & $15-50$ & $31-61$ \\
U-234 & $13-63$ & $15-89$ & $37-52$ \\
Th-230 & $631-978$ & $32-68$ & $251-392$ \\
Ra-226 & $450-1251$ & $104-236$ & $249-594$ \\
Pb-210 & $539-1163$ & $136-228$ & $303-581$ \\
Po-210 & $541-801$ & $115-203$ & $255-344$ \\
Th-232 & $47-346$ & $57-349$ & $61-285$ \\
Ra-228 & $163-334$ & $90-238$ & $90-247$ \\
Th-228 & $166-253$ & $47-169$ & $178-209$ \\
\hline
\end{tabular}

From $[13,14,15,16,17]$

\section{BRAZILIAN SAFETY STANDARDS FOR THE USE OF NORM PRODUCTS}

In Brazil, the regulatory agency (Comissão Nacional de Energia Nuclear - CNEN) published a standard, CNEN NN 4.01, concerned with mining and milling of natural occurring radioactive material, which may generate enhanced concentrations of radionuclides, under the radiological protection point of view [18]. Such activities include the mining and processing of ores as well as storage of raw material, products, by-products, residues and wastes containing radionuclides of the U-238 and Th-232 series, which may incur undue exposures of members of the public and occupationally exposed. According to this standard CNEN NN 4.01, the phosphate industry activity is classified in category III due to the levels of radioactivity present in the phosphogypsum. To comply with the statements of this guideline, the installation should evaluate the environmental impact of the disposal of phosphogypsum. 
The presence of radionuclides puts restrictions on the use of PG as building materials and as soil amendments. The Brazilian regulatory body ruled that phosphogypsum would only be permitted for use in agriculture or in the cement industry if the concentration of ${ }^{226} \mathrm{Ra}$ and ${ }^{228} \mathrm{Ra}$ does not exceed 1 $\mathrm{Bq} \mathrm{g}^{-1}[19]$.

In 2014, a working group was established at the national regulatory level in Brazil, aiming to define a policy for using phosphogypsum as construction material. The adopted approach was to limit the concentration of phosphogypsum to be mixed with natural gypsum, based on ${ }^{226} \mathrm{Ra}$ and ${ }^{228} \mathrm{Ra}$ concentrations found in phosphogypsum [20]. However, this guideline was cancelled two years after its implementation.

\section{PHOSPHOGYPSUM USE AS BUILDING MATERIAL}

Only a relatively small portion of the worldwide phosphogypsum produced (14\%) is reprocessed and used as building material. However, it contains relatively high amounts of radioactivity originated mainly from the ${ }^{238} \mathrm{U}$ and ${ }^{232} \mathrm{Th}$ decay series, which can cause health hazards in dwellers. ${ }^{226} \mathrm{Ra}$, which decays to ${ }^{222} \mathrm{Rn}$ through an alpha particle emission, is one of the most important radionuclides from the point of view of radiation protection. The principal health hazard associated with ${ }^{222} \mathrm{Rn}$ is due to its short-lived alpha emitter's daughter products, which can cause damage to the lungs after chronic exposure. Therefore, its safe utilization requires an evaluation of the radiological impact in dwellers, which comprises the evaluation of internal exposure due to radon inhalation and external exposure due to gamma radiation.

\subsection{Internal exposure in dwellers due to inhalation of $R \mathbf{n}$}

The internal exposure indoors depends mainly on the activity concentration of ${ }^{226} \mathrm{Ra}$ and ${ }^{228} \mathrm{Ra}$ in the construction material and the radon exhalation rate, which can be determined by using theoretical models or measured experimentally.

The exhalation rate is defined as the amount of activity released per unit surface area per unit time from the material. It depends on the ${ }^{226} \mathrm{Ra}$ content of the material, emanation factor, gas diffusion coefficient in the material, porosity and density of the material. 
The exhalation of radon was initially measured experimentally in the phosphogypsum piles from the main phosphate fertilizer industries [21] (Figure 15).

The methodology used was the activated charcoal collector method [22]. The ${ }^{222} \mathrm{Rn}$ exhalation rate from phosphogypsum was calculated through the ${ }^{214} \mathrm{~Pb}$ and ${ }^{214} \mathrm{Bi}$ concentrations, considering that the adsorption of ${ }^{222} \mathrm{Rn}$ on activated charcoal collector was constant and with $100 \%$ efficiency [22]; all results were corrected by date of removal of the phosphogypsum collector and its exposure period.

Figure 15: Phosphogypsum stack

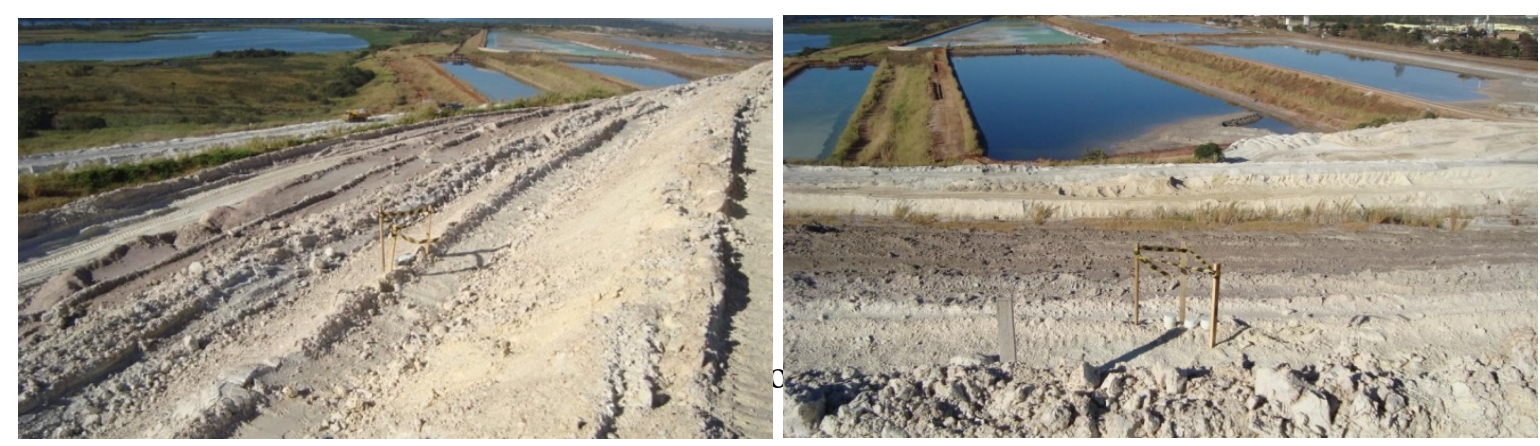

A theoretical model for radon exhalation calculation, suggested by UNSCEAR [23], was also applied in order to corroborate the experimental results. In this case, the radon exhalation rate was determined through the ${ }^{226} \mathrm{Ra}$ concentration from phosphogypsum, the real density and total porosity of phosphogypsum. This model is used for the evaluation of the flux density of ${ }^{222} \mathrm{Rn}$ at a surface of dry soil, according to the following equation 1 :

$$
J_{D}=C_{R a} \cdot \lambda_{R n} \cdot f \cdot \rho_{s} \cdot(1-\varepsilon) \cdot L
$$

where:

$J_{D}=$ flux density of ${ }^{222} \mathrm{Rn}$ at the surface of dry soil $\left(\mathrm{Bq} \mathrm{m}^{-2} \mathrm{~s}^{-1}\right)$

$C_{R a .}=$ concentration of radium in soil $\left(\mathrm{Bq} \mathrm{kg}^{-1}\right)$

$\lambda_{R n}=$ decay constant of ${ }^{222} \mathrm{Rn}\left(\mathrm{s}^{-1}\right)$

$f=$ emanation fraction

$\rho_{s}=$ real density $\left(\mathrm{kg} \mathrm{m}^{-3}\right)$ 
$\varepsilon=\quad$ total porosity $(\%)$

$L=$ diffusion length of ${ }^{222} \mathrm{Rn}(\mathrm{m})$.

The results obtained are presented in Table 2. The results obtained for the radon exhalation rate obtained experimentally and with the UNSCEAR model are quite similar. Although the ${ }^{226} \mathrm{Ra}$ activity concentration of phosphogypsum from Uberaba and Cubatão installations are similar, the corresponding radon exhalation rate are different, showing that the porosity plays an important role in the exhalation of the radon gas.

Table 2: Bulk density, real density, total porosity and ${ }^{222} \mathrm{Rn}$ exhalation rate from Cubatão and Uberaba phosphogypsum stacks

\begin{tabular}{|c|c|c|c|c|c|}
\hline Sampling location & $\begin{array}{c}\text { Bulk } \\
\text { density } \\
\left(\mathrm{g} \cdot \mathrm{cm}^{-3}\right)\end{array}$ & $\begin{array}{c}\text { Real } \\
\text { Density } \\
\left(\mathrm{g} \cdot \mathrm{cm}^{-3}\right)\end{array}$ & $\begin{array}{c}\text { Total } \\
\text { porosity } \\
(\%)\end{array}$ & 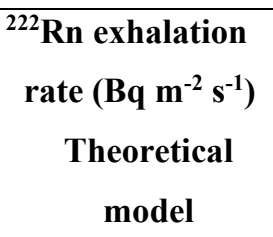 & 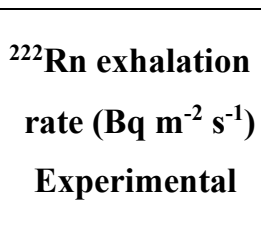 \\
\hline & 1.21 & 2.40 & 49.6 & 0.161 & $0.083-0.102$ \\
\hline Cubatão & 1.20 & 2.63 & 54.4 & 0.155 & $0.195-0.214$ \\
\hline \multirow[t]{2}{*}{${ }^{226} \mathrm{Ra}=308-324 \mathrm{~Bq} \mathrm{~kg}^{-1}$} & 1.20 & 2.39 & 49.7 & 0.156 & 0.268 \\
\hline & 1.20 & 2.69 & 55.4 & 0.152 & 0.119 \\
\hline \multirow[t]{2}{*}{ mean \pm standard deviation } & & & & $0.156 \pm 0.004$ & $0.164 \pm 0.073$ \\
\hline & 0.76 & 2.64 & 71.1 & 0.092 & $0.070-0.073$ \\
\hline Uberaba & 0.76 & 2.38 & 67.9 & 0.086 & $0.051-0.053$ \\
\hline \multirow[t]{2}{*}{${ }^{226} \mathrm{Ra}=291-357 \mathrm{~Bq} \mathrm{~kg}{ }^{-1}$} & 0.76 & 2.50 & 69.6 & 0.111 & $0.091-0.098$ \\
\hline & 0.75 & 2.50 & 69.9 & 0.090 & $0.082-0.115$ \\
\hline mean \pm standard deviation & & & & $0.094 \pm 0.011$ & $0.079 \pm 0.022$ \\
\hline
\end{tabular}

The radon exhalation rate from bricks and plates made of phosphogypsum (Figure 16) from three installations of the Mosaic industry: Cubatão, Uberaba and Cajati, were evaluated theoretically by using the model from UNSCEAR [23] for building material, through the ${ }^{226} \mathrm{Ra}$ concentration and experimentally, by using the CR-39 method. 
This model is used for the evaluation of the radon exhalation rate from bricks and plates made of phosphogypsum, according to the following equation 2 :

$$
J_{D}=C_{R a} \lambda_{R n} f \rho L \tanh (d / L)
$$

where

$J_{D} \quad$ is the radon exhalation rate of ${ }^{222} \mathrm{Rn}\left(\mathrm{Bq} \mathrm{m}^{-2} \mathrm{~h}^{-1}\right)$,

$C_{R a}$ is the activity concentration of ${ }^{226} \mathrm{Ra}\left(\mathrm{Bq} \mathrm{kg}_{-}{ }^{1}\right)$,

$\lambda_{R n} \quad$ is the decay constant of ${ }^{222} \mathrm{Rn}\left(\mathrm{h}^{-1}\right)$,

$f \quad$ is the emanation fraction,

$\rho \quad$ is the density $\left(\mathrm{kg} \mathrm{m}^{-3}\right)$,

$d \quad$ is half-thickness $(\mathrm{m})$,

$L \quad$ is the diffusion length $\left(\mathrm{m}^{2}\right)$.

The practical approach consisted of measuring the radon exhalation rate directly from the surface of the material to allow radon to build up in a container over time. The device used to this practical radon measurement was the accumulator (Figure 17). The results obtained for the radon exhalation rate from plates and bricks made of phosphogypsum were compared with other conventional building materials (Table 3). The results obtained are of the same order of magnitude. Therefore, it can be concluded that the plates and bricks manufactured with phosphogypsum from these producers may be used as a building material, posing no additional health risk to dwellers due to radon exhalation rate.

The recycling of phosphogypsum for building materials manufacturing can be a safe alternative, considering its radon exhalation rate.

Figure 16: Bricks and plates made of phosphogypsum
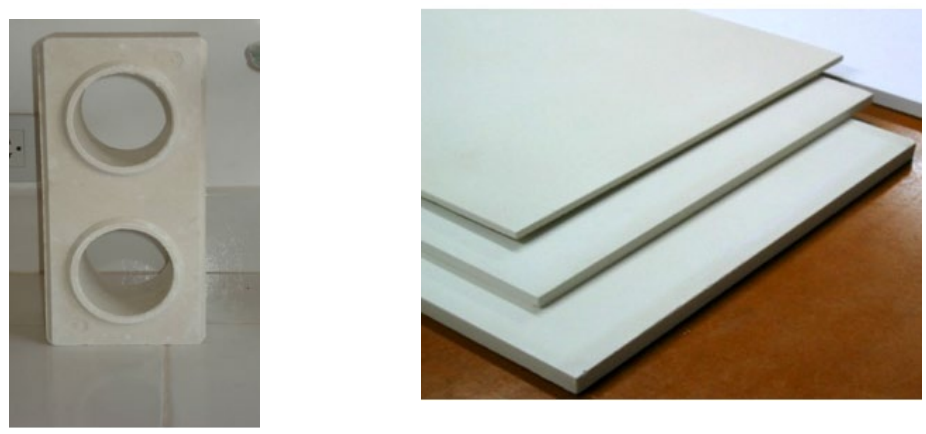
Figure 17: (a) Phosphogypsum bricks and accumulation chamber /(b) phosphogypsum plates and accumulation chamber / (c) CR-39 radon dosimeter / (d) Track density measurements system

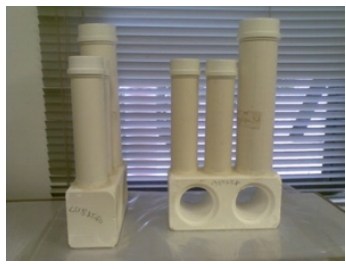

(a)

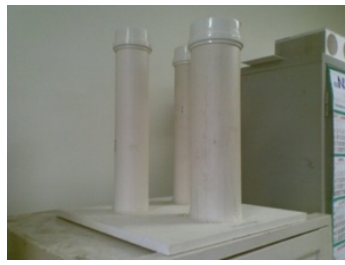

(b)

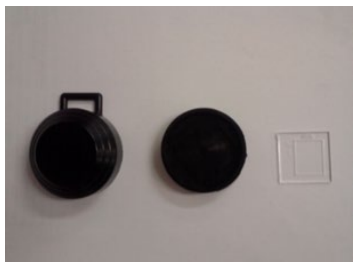

(c)

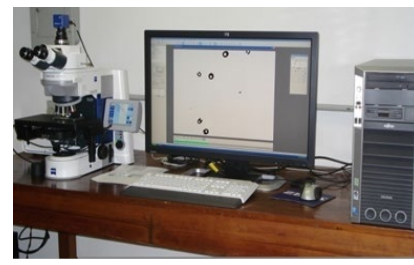

(d)

Table 3: Radon exhalation rate from bricks and plates made of phosphogypsum and other construction materials $\left(\mathrm{Bq} \mathrm{m}^{-2} \mathrm{~h}^{-1}\right)$

\begin{tabular}{lcc}
\hline Building Material & ${ }^{222}$ Rn exhalation rate & References \\
\hline Phosphogypsum Stack & $341-562$ & {$[21]$} \\
Phosphogypsum Stack & $284-590$ & {$[21]$} \\
Gypsum Brick & $0.08-0.29$ & {$[24]$} \\
Phosphogypsum Brick & $0.03-1.89$ & {$[24]$} \\
Phosphogypsum Brick & $0.41-5.67$ & {$[25]$} \\
Phosphogypsum Brick & $6-10$ & {$[26]$} \\
Gypsum Plate & $0.2-18.4 *$ & {$[28]$} \\
Phosphogypsum Plate & $0.14-1.30$ & {$[24]$} \\
Phosphogypsum Plate & $0.16-4.30$ & {$[25]$} \\
Phosphogypsum Plate & $2.2-4.8$ & {$[29]$} \\
Crude Brick & 0.16 & {$[30]$} \\
Granite & $0.16-1.4$ & {$[31]$} \\
Cement & $0.27-0.66$ & {$[29]$} \\
Cement & $0.18-0.91$ & {$[32]$} \\
Concrete & 4.32 & {$[33]$} \\
Soil & $2.2-2.8$ & {$[34]$} \\
Sand & $3.9-16.7$ & {$[34]$} \\
Slate & $0.36-1.9$ & {$[35]$} \\
\hline
\end{tabular}

*Phosphogypsum 


\subsection{Internal and external exposure in dwellers}

The external and internal exposure in dwellers due to gamma irradiation can be evaluated by applying radium equivalent activity and external and internal hazard indices from bricks and plates made of phosphogypsum. The radium equivalent activity was obtained by the equation (3) [36]:

$$
C_{R a, e q}=C_{R a}+1.43 C_{T h}+0.077 C_{K}
$$

where

CRa,eq is the radium equivalent activities $\left(\mathrm{Bq} \mathrm{kg}^{-1}\right)$,

$\mathrm{CRa}$ is the activity concentrations of ${ }^{226} \mathrm{Ra}\left(\mathrm{Bq} \mathrm{kg}^{-1}\right)$,

$\mathrm{CTh}$ is the activity concentrations of ${ }^{232} \mathrm{Th}\left(\mathrm{Bq} \mathrm{kg}^{-1}\right)$,

$\mathrm{CK}$ is the activity concentrations of ${ }^{40} \mathrm{~K}\left(\mathrm{~Bq} \mathrm{~kg}^{-1}\right)$,

$1,1.43$ and 0.077 index values were defined on hypothesis that $370 \mathrm{~Bq} \mathrm{~kg}{ }^{-1}, 259 \mathrm{~Bq} \mathrm{~kg}^{-1}$ and 4810 $\mathrm{Bq} \mathrm{kg}{ }^{-1}$ for ${ }^{226} \mathrm{Ra},{ }^{232} \mathrm{Th}$ and ${ }^{40} \mathrm{~K}$ produce the same gamma ray exposure.

External hazard index was calculated using the equations (4) and (5), respectively [36].

$$
\begin{aligned}
& \frac{C_{R a}}{370}+\frac{C_{T h}}{259}+\frac{C_{K}}{4810} \leq 1 \text { for external exposure } \\
& \frac{C_{R a}}{185}+\frac{C_{T h}}{259}+\frac{C_{K}}{4810} \leq 1 \text { for internal exposure }
\end{aligned}
$$

where

$C_{R a}$ is the activity concentrations of ${ }^{226} \mathrm{Ra}\left(\mathrm{Bq} \mathrm{kg}^{-1}\right)$,

$C_{T h}$ is the activity concentrations of ${ }^{232} \mathrm{Th}\left(\mathrm{Bq} \mathrm{kg}^{-1}\right)$,

$C_{K}$ is the activity concentrations of ${ }^{40} \mathrm{~K}\left(\mathrm{~Bq} \mathrm{~kg}^{-1}\right)$,

370,259 and 4810 are the indices for external exposure,

185,259 and 4810 are the indices for internal exposure. 
The results of radium equivalent, external and internal hazard indices (Table 4) showed that plates and bricks from Cubatão and Uberaba present values above the recommended limits, suggesting the application of a more realistic scenario for the evaluation of the exposure in dwelling for the safe application of phosphogypsum as building material.

Table 4: Radium equivalent activities in $\mathrm{Bq} \mathrm{kg}^{-1}$ (CRa,eq) and external and internal hazard indices from [25].

\begin{tabular}{lccc}
\hline Samples & $\mathbf{C}_{\text {Ra,eq }}$ & \multicolumn{2}{c}{ Hazard indices } \\
\cline { 3 - 4 } (bricks/plates) & $\left(\mathbf{B q ~ k g}^{-1}\right)$ & ext. & int. \\
\hline bricks (Cubatão) & 780 & 2.1 & 3.2 \\
bricks (Uberaba) & 559 & 1.5 & 2.3 \\
bricks (Cajati) & 84 & 0.2 & 0.3 \\
plates (Cubatão) & 755 & 2.0 & 3.1 \\
plates (Uberaba) & 512 & 1.4 & 2.2 \\
plates (Cajati) & 55 & 0.2 & 0.2 \\
\hline recommended limits & 370 & 1 & 1 \\
\hline
\end{tabular}

\subsection{The experimental house}

In order to assess the feasibility of using phosphogypsum as building material, an experimental house was built with phosphogypsum plates of different origins (Figure 18). The house was entirely lined with phosphogypsum and designed to perform a comprehensive radiological evaluation, including the modelling of the external dose indoors, measurement of the external gamma exposure and of radon concentrations [27]. The plates were manufactured with phosphogypsum from different producers, located in in Cubatão, Cajati and Uberaba. At the house a bedroom and bathroom were built with phosphogypsum plates from Cubatão and other bedroom was built with Cajati phosphogypsum plates (Figure 19). 
Figure 18: Experimental house built with phosphogypsum plates
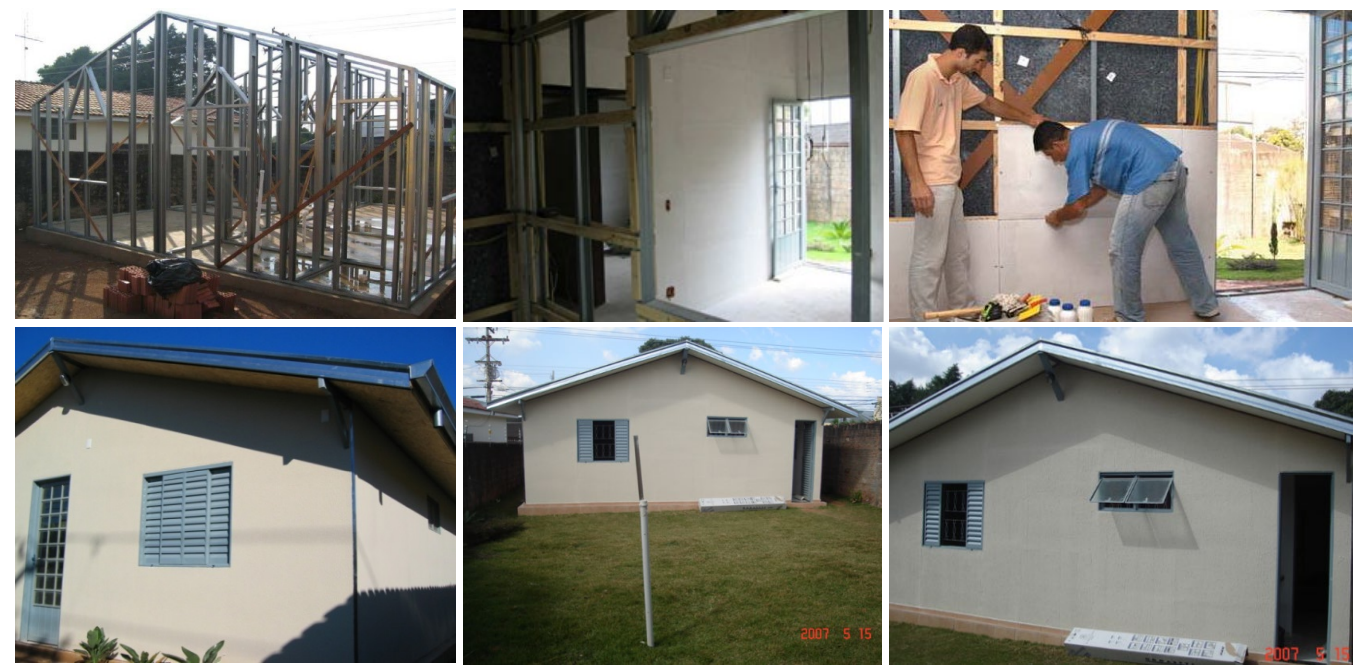

Figure 19: Floor plan of the experimental house built with gypsum boards [27]

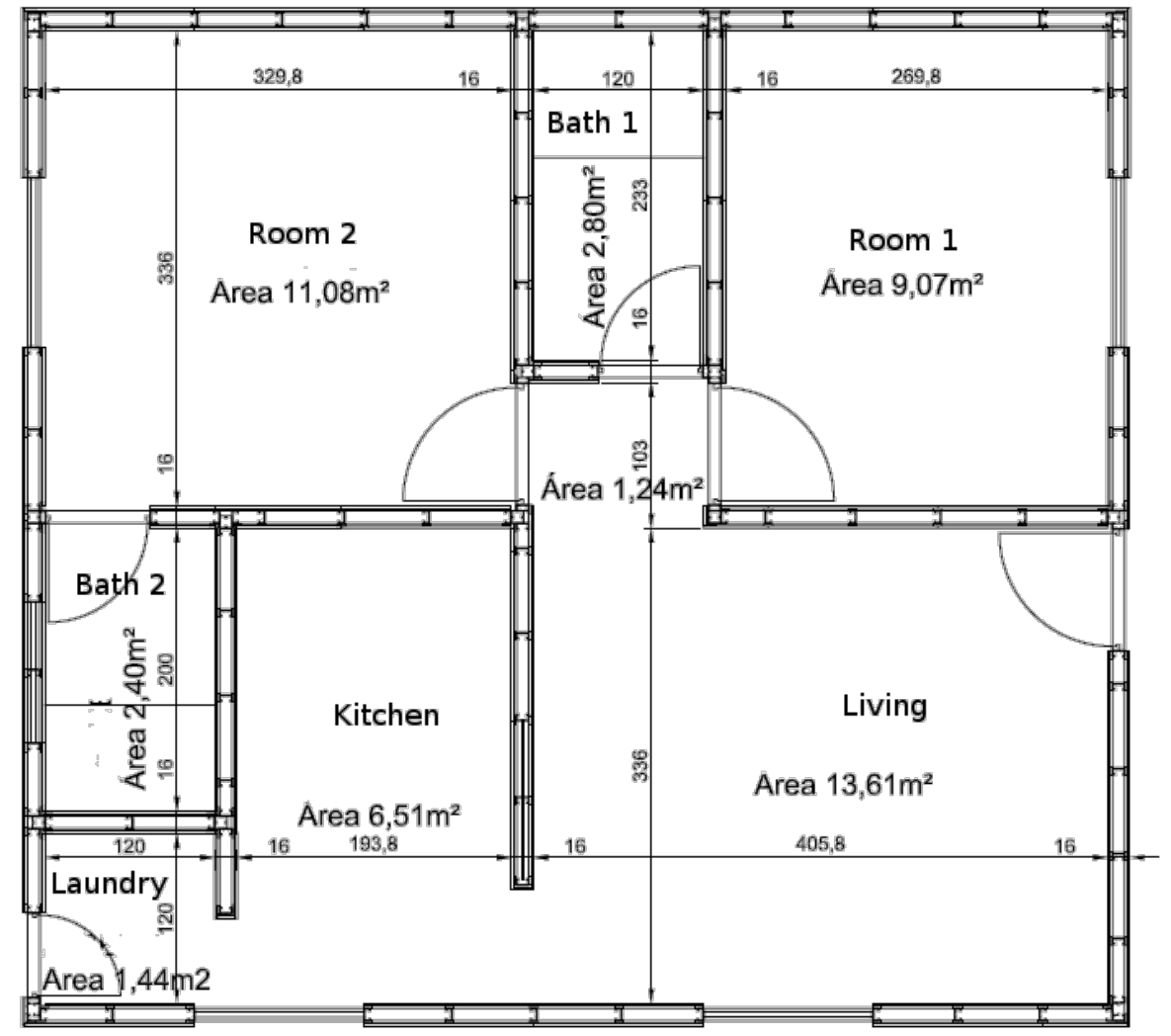


In this experimental house it was possible to evaluate the dose conversion factors for the external exposure and to evaluate the real annual increment in the effective dose to an inhabitant of the house, which was below the $1 \mathrm{mSv}$ limit for every reasonable scenario.

The theoretical dose conversion factors derived for that experimental house in units of $n G y \mathrm{~h}^{-1}$ per Bq kg${ }^{-1}$ are 0.08 for ${ }^{226} \mathrm{Ra}, 0.103$ for ${ }^{232} \mathrm{Th}$, and 0.00776 for ${ }^{40} \mathrm{~K}$ [27].

The radon measurements were carried out over a period of 18 months, in order to determine the long-term average levels of the indoor radon concentrations. The radon concentrations varied from 45 to $50 \mathrm{Bqm}^{-3}$ in the bedroom built with phosphogypsum plates from Cajati and from 83 to $119 \mathrm{~Bq}$ $\mathrm{m}^{-3}$ in the bedroom and bathroom built with phosphogypsum from Cubatão.

The results obtained are below $300 \mathrm{~Bq} \mathrm{~m}^{-3}$, the recommended investigation level for radon by ICRP in dwellings. It should be observed that the radon concentration results took into account the radon from soil under the construction.

The results obtained for the radon concentration in dwelling made of phosphogypsum is comparable to the radon concentration in conventional building material houses.

\section{CONCLUSION}

The use of building materials with elevated or technologically enhanced levels of natural radioactivity could in principle be a reason of higher external and internal doses for residents.

However, it should be considered that the models for the evaluation of the external gamma dose, based on radiation indexes calculated for specific geometries of standard rooms, are intrinsically conservative, since they aim to establish criteria for the safe use from the radiological point of view, rather than determining exact values of the resulting indoors doses. Several authors have proposed models applied to specific, more realistic situations.

On the other hand, it is becoming evident that there is a need to validate the various models that have been proposed, by means of direct measurements of the external gamma dose and the concentrations of ${ }^{222} \mathrm{Rn}$ predicted from the concentration of NORM in the materials used in the houses. In this line of action, the proposal is to verify to what extent the semi-empirical models used in the modeling of the physical processes involved in the use of NORM materials in civil construction are 
confirmed by real measurements. There are several relevant physical processes that require specific studies, namely:

- Evaluation of the exhalation rate of radon from $\mathrm{CaSO}_{4}$ present in the phosphogypsum piles to the atmosphere;

- Evaluation of exhalation rate of radon from the building material made of phosphogypsum and consequent inhalation by individuals indoors;

- Evaluation of the radon retention inside the building material and its influence in the gamma radiation levels arising from the radon daughters.

Each of these studies requires specific modeling and its validation by direct determination of external doses indoors and ${ }^{222} \mathrm{Rn}$ concentrations. Several of these aspects have been approached, to a certain extent, by this research group in Brazil.

There is a great advantage in using a real dwelling constructed with phosphogypsum based materials for the specific purpose of conducting a radiological evaluation, considering the contents of radioactivity and realistic room modeling using the detailed structural specifications, instead of reference rooms.

The dose assessment based on a real scenario, where a given material is used, provides realistic conclusions that can help in making decisions about the applicability of new materials. The methodology developed so far can be applied to other building materials by using appropriate adjustments.

Considering the important role of recycling abundant industrial residue and preserve natural sources for a sustainable development, it is encouraged to use phosphogypsum instead of natural gypsum as construction material. Nowadays, the need to seek solutions aiming to reduce existing waste by-products is stressed by IAEA, in the document GSR Part 3 [37].

As a final conclusion, it is emphasized that the research carried out over the last 2 decades has shown that the application of Brazilian phosphogypsum as a construction material is safe from the point of view of radiation protection and is economically feasible, provided that adequate regulation is implemented.

The next challenge, based on the research carried out so far, is to develop new phosphogypsumbased building materials, and provide a practical and legal framework for the safe use of phosphogypsum. A preliminary proposal for regulation, adopting the strategy of minimizing the poten- 
tial dose by means of controlled mixture of phosphogypsum with natural gypsum, was recently presented by [38].

\section{ACKNOWLEDGEMENTS}

This project was supported by Fundação de Amparo à Pesquisa do Estado de São Paulo (FAPESP), research contract 2006/01112-3, and by Conselho Nacional de Desenvolvimento Científico e Tecnológico (CNPq), grant 300835/95-7.

\section{REFERENCES}

[1] U.S. GEOLOGICAL SURVEY. Mineral commodity sumaries 2017. U.S. Geological Survey, p.202, https://doi.org/10.3133/70180197, 2017.

[2] IAEA - International Atomic Energy Agency. Radiation Protection and Management of NORM Residues in the Phosphate Industry - Safety Report Series 78, ed. Vienna: International Atomic Energy Agency, 2013.

[3] MACÍAS, F.; PÉREZ-LÓPEZ, R.; CÁNOVAS, C.R.; CARRERO, S.; CRUZ-HERNANDEZ, P. Environmental assessment and management of Phosphogypsum according to European and United States of America regulations, Procedia Earth Planet Sci, v. 17 p. 666 - 669, 2017.

[4] DNPM - Departamento Nacional de Produção Mineral. Sumário Mineral (2016). Available at: <http://www.dnpm.gov.br/dnpm/sumarios/sumario-mineral-2015>. Last acessed: 8 Dec. 2017.

[5] IBRAM - Information and Analyses on the Brazilian Mineral Economy. IBRAM-7th edition (2012). Available at: http://ibram.org.br/sites/1400/1457/00000380.pdf. Last accessed 8 Dec. 2017.

[6] VALE. Operações e Projetos.

Available at; http://www.valefertilizantes.com/valefertilizantes/operacoes.asp. Last acessed: 4 Jan. 2018.

[7] NISTI, M.B. Lixiviation of natural radionuclides and heavy metals in tropical soils amended with phosphogypsum (Doctoral dissertation). Retrieved from the Digital Library of Theses and Dissertations of the University of São Paulo, 2016. 
[8] DRAFTTDATA. Novo sistema de bombeamento de fosfogesso. Available at: http://draftdata.com.br/novo-sistema-de-bombeamento-de-fosfogesso. Last accessed 21 Feb. 2018.

[9] RIMA. Relatório de Impacto Ambiental (2014). Available at: http://www.consorciosantaquiteria.com.br/arquivos/RIMA.pdf. Last accessed 21 Feb. 2018.

[10] BORGES R.C., RIBEIRO F.C.A., LAURIA D.C., BERNEDO A.V.B. Radioactive characterization of phosphogypsum from Imbituba, Brazil. J Environ Radioact, v. 126, p. 188-195, 2013.

[11] BORGES, R.C. Caracterização química e radiológica do fosfogesso de Imbituba-SC e aspectos ambientais do uso na recuperação de solos agrícolas (Doctoral dissertation). Retrieved from the Universidade Federal Fluminense, 2011.

[12] BORGES R.C., FERREIRA A.A., DE SOUZA W.F.L., BERNEDO A.V.B. The Geochemistry of Natural Radionuclides in Saline Soils from Brazil Treated with Phosphogypsum Imbituba. Water Air Soil Pollut, v. 228, p. 592017.

[13] MAZZILLI B.P., PALMIRO V., SAUEIA C.H., NISTI M.B. Radiochemical characterization of Brazilian phosphogypsum, J Environ Radioact, v. 49(1), p. 113-122, 2000.

[14] SAUEIA C.H.R., MAZZILLI B.P., FÁVARO D.I.T. Natural radioactivity in phosphate rock, phosphogypsum and phosphate fertilizers in Brazil, J Radioanal Nucl Chem, v. 264 (2). P. 445-448, 2005.

[15] SAUEIA C.H.R., MAZZILLI B.P., Distribution of Natural Radionuclides in the Production and Use of Phosphate Fertilizers in Brazil, J Environ Radioact, v. 89, p. 229-239, 2006.

[16] SAUEIA C.H.R., MAZZILLI B.P., TADDEI M.H.T. Sequential radioanalytical method for the determination of $\mathrm{U}$ and $\mathrm{Th}$ isotopes, 226Ra and 210Po using alpha spectrometry in samples of the Brazilian phosphate industry, J Radioanal Nucl Chem, v. 281, p. 201-204, 2009.

[17] MAZZILLI, B.P.; SAUEIA, C.H.R.; JACOMINO, V.M.F.; MELLO, J.W.V. Natural radionuclides and metals intake into soya, corn and lettuce grown on soil amended with phosphogypsum. Int J Environ Anal Chem, v. 92, p. 1574-1586, 2012.

[18] CNEN - Comissão Nacional de Energia Nuclear. Requisitos de Segurança e Proteção Radiológica para Instalações Mínero-Industriais - Norma CNEN NN 4.01, ed. Diário Oficial da União (DOU), Resolução CNEN 208/16, 2016. 
[19] CNEN - Comissão Nacional de Energia Nuclear. Nível de isenção para o uso do fosfogesso na agricultura ou na indústria cimenteira - Resolução n 147, Brasília, 2013.

[20] CNEN - Comissão Nacional de Energia Nuclear - BS No 09 de 16/05/2014. Resolução $\mathbf{n}^{\circ}$ 171, Brasília, 2014.

[21] NISTI, M.B., CAMPOS, M.P., MAZZILLI, B.P.,. Natural radionuclides content and radon exhalation rate from Brazilian phosphogypsum piles. J Radioanal Nucl Chem, v. 299, p. 261264, 2014.

[22] DUEÑAS, C., LIGER, E., CAÑETE, S., PÉREZ, M., BOLÍVAR, J.P., Exhalation of 222Rn from phosphogypsum piles located at the southwest of Spain. J Environ Radioact, v. 95, p. 6374. 2007.

[23] UNSCEAR - United Nations Scientific Committee on the Effects of Atomic Radiation, The 2000 Report to the General Assembly with scientific Annexes. New York: United Nations, 2000.

[24] M.P CAMPOS, L.J.P. COSTA, M.B. NISTI, B.P. MAZZILLI. Phosphogypsum recycling in the building materials industry: assessment of the radon exhalation rate. J Environ Radioact, v. 172, p. 232-236, 2017.

[25] NISTI, M.B., CAMPOS, M.P., MAZZILLI, B.P. Natural radioactivity and 222Rn exhalation rate from Brazilian phosphogypsum building materials. In: 7TH INTERNATIONAL SYMPOSIUM ON NATURALLY OCCURRING RADIOACTIVE MATERIAL, 2013, Beijing. Proccedings of 7 th International Symposium on Naturally Occurring Radioactive Material (Supplementary Material). International Atomic Energy Agency, Vienna, 2013. p. 1-6.

[26] FOURNIER, F., GROETZ, J.E., JACOB, F., LETTNER, H., CHAMBAUDET, A., CROLET, J.M. Study of Radon-222 exhalation of phosphogypsum blocks used as building materials. Comparison with modeling. Radioact Environ, v. 7, p. 582-589, 2005

[27] MÁDUAR, M.F.; CAMPOS, M.P.; MAZZILLI, B.P.; VILLAVERDE, F.L. Assessment of external gamma exposure and radon levels in a dwelling constructed with phosphogypsum plates, J Hazard Mater, v. 190, p. 1063-1067, 2011.

[28] FOLKERTS, K.H., KELLER, G., MUTH, H. An experimental study on diffusion and e exhalation of 222Rn and 220Rn from building materials. Radiat Prot Dosim, v. 9(1), p. 27-34, 1984. 
[29] LETTNER, H., STEINHAUSLER, F. Radon exhalation of waste gypsum recycled as building materials. Radiat Prot Dosim, v. 24, p. 415-417, 1988.

[30] SHARMA, N., VIRK, H.S. Exhalation rate study of radon/thoron in some building materials. Radiat Meas, v. 34, p. 467-469, 2001.

[31] KOTRAPPA, P., STIEFF, F. Radon exhalation rates from building materials using electret ion chamber radon monitors in accumulators. Health Phys, V. 97(2), p. 163-166, 2009.

[32] SHARAF, M., MANSY, M., SAYED, A.E.L., ABBAS, E. Natural radioactivity and radon exhalation rates in building materials used in Egypt. Radiat Meas, v. 31, p. 491-495, 1999.

[33] DE JONG, P., VAN DIJK, W., VAN DER GRAAF, E.R., DE GROOT, T.J.H. National survey on the natural radioactivity and $222 \mathrm{Rn}$ exhalation rate of building materials in The Netherlands. Health Phys, v. 91, p. 200-210, 2006

[34] RAHAMA, S., MATI, N., MATIULLAH, N., GHAURI, B. Radon exhalation rate from the soil, sand and brick samples collected from NWFP and fata. Pak. Radiat Prot Dosim, v. 124, p. 392-399, 2007.

[35] CHEN, J., RAHMAN, N.M., ATIYA, I.A. Radon exhalation from building materials for decorative use. J Environ Radioact, v. 101, p. 317-322, 2010

[36] BERETKA, J., MATHEW, P.J. Natural Radioactivity of Australian Building Materials, Industrial Wastes and By-products”, Health Phys, v. 48, p. 87-95, 1985.

[37] IAEA - International Atomic Energy Agency. Radiation Protection and Safety of Radiation Sources: International Basic Safety Standards - Safety Standards Series No. GSR Part 3. Ed. Vienna: International Atomic Energy Agency, 2014.

[38] MÁDUAR, M.F.; MAZZILLI, B.P.; NISTI, M.B. Radiation hazard indices in the application of phosphogypsum mixtures as a building material: proposal for a Brazilian regulation. Brazilian J Radiat Sciences, v. 07-03, p. 01-13, 2019. 